\title{
Body and image
}

\section{Maria POPCZYK*}

\begin{abstract}
In aesthetics, as a philosophy of art, the body of the viewer is juxtaposed with the image of the painting, before which it stands still; both body and image are considered to be independent, which is a condition of a full aesthetic experience. In the present article I demonstrate how, through phenomenology, pragmatism and the idea of incarnation, post-Kantian aesthetic is broadened. I limit myself to three theoretical perspectives; in each of them the duality of body and image is neutralised according to different rules. Phenomenology develops the relations between consciousness and body, while in pragmatism the encounter of body and image takes place in the process of the performative creation of image. The idea of incarnation, on the other hand, develops both of these currents in two divergent approaches: a theological and an anthropological one. Bringing together perspectives, which are so different methodologically reveals the existence of a profound tie between body and image.
\end{abstract}

\section{KEYWORDS}

visual culture; body; image; icon; incarnation; anthropology

* Ph.D. (habil.), Associate Professor of University of Silesia in Katowice, Chair of the Department of Aesthetics and Anthropology of Space, Poland. E-mail: maria.popczyk@us.edu.pl. 
For several decades now, image has been an object of research in its own right. Philosophers, aestheticians, art historians and cultural scholars have shown it to be an important tool of our cultural self-consciousness and gave it a rank it had never possessed before (Mitchell, 2005), placing it right next to conceptions. In reflection on image, its double nature is emphasised: it is created as an effect of perception (it is a mental image of memory, material of thought and imagination), and is present both in daydreams and the dreams we have at night. It participates in cognitive processes and ethical choices, it is experienced emotionally, it is constructed, and it haunts us in our sleep. But in common understanding, image is identified as a physical or virtual object, a product of an artist, designer, or a computer, which is encountered in art galleries, shops, in the streets, on the walls of buildings, on the covers of magazines and on all sorts of screens. This kind of image offers representations, projections, fictions, and above all views. Martin Heidegger, explaining Kant's use of the word "image", writes:

First of all, image can mean: the look of a determinate being to the extent that it is manifest as something at hand. It offers the look. As a derivation of this meaning, image can also mean: the look which takes a likeness of something at hand (likeness), i.e., a look which is the after-image of something no longer at hand or a look which is the premonition of a being [yet] to be produced for the first time (Heidegger, 1990: 65).

Both the imagined and the artefactual image have the ability to move us profoundly, to affect our mind and our corporeal-sensual condition, making the world both direct and our own. I am interested in the relations and dependencies that occur between the human body and the physical and/or mental image from the perspective of art and aesthetics. The idea of searching for such relations was born from two tendencies in research and art, that is theories focused on the body and the pictorial turn, which traces various functions of image. Aesthetics - especially the aesthetics of disinterestedness - clearly juxtaposes body and image in the process of aesthetic experience, which is the domain of reflexive taste. The body of an art lover is subject to discipline, imposed with the aid of sterile spaces of museums and galleries. In philosophy body is considered to be less important and perhaps even seen as getting in the way of conscious life, and so not determining factor for the identity of the rational man. In natural sciences it is treated as an object with particular physical parameters, subject to study; it is what in German is described with the word Körper - as opposed to the notion of Leib, which covers corporeality understood as intimate interiority, felt subjectivity. ${ }^{1}$ This distinction demonstrates

\footnotetext{
${ }^{1}$ Using the notions of Körper and Leib, specific to German language, allows us to distinguish body as experienced from the outside, material and physical, from body as experienced from the inside. For more on the different meanings of Körper and Leib see Diemer,
} 
that body can be treated as an object of manipulation. Even the gaze of the Other has the power to objectify, as Jean Paul Sartre has proven. Our dislike of being observed, monitored and photographed comes from the fact that we do not identify with the image of ourselves that is produced by these acts. ${ }^{2}$ Nevertheless, human beings themselves direct their bodies, subject them to their will, that is objectify their own bodies, which means we possess bodies, and in possessing we direct them, show them to others, adopting specific social roles, which are imposed on us or which we take on ourselves. This does not change the fact that we also are corporeality experienced from within. Roland Barthes captured the problems this situation involves when he was being photographed. He stated: "I am neither subject nor object but a subject who feels he is becoming an object [...] I have become Total-Image, which is to say, Death in person" (Barthes, 1981: 14). Barthes rebels against his person being reduced to an image.

Alongside philosophical stances, or independently of them, approaches to the human body are being altered through media images and through a turn towards studying types of images previously ignored; for example, Didi $\mathrm{Hu}-$ berman extends the study of image to dream images (Didi-Huberman, 2011: 97-153). Body and image are not juxtaposed, but encounter one another, entering into relations within the space of sensation and experience, as well as in the spaces of creation. Images are no longer merely watched, but are also touched and used, and when they combine into light projections, they become an environment in which the user moves. This is why we may distinguish at least two different types of situation in which bodies and images enter into relations with one another. The first of those concerns the reception of the work of art/the artefact in phenomenology: the body of the viewer and the physical artefact are neutralised, and the relation between body and image plays out in the intentional consciousness. The second happens when the body is in tactile interaction with the image in a physical or virtual space, which is enforced by the work/artefact. This situation has two versions: one is the performative process of creating the work/artefact - this includes the proposal of pragmatism, while the other uses the ideas of incarnation, as is the case with the theology of the icon and Hans Belting's anthropology of images. Thus, I am considering the existence of body and image as relatively autonomous and potentially forming a relation, but I am not interested in body as an expression of the soul or the character, as physiognomics and visual communication do, or in body creating images, as a mime or actor does. Artists provide ample

1981: 58-61. Also, Marek Drwięga makes some pervasive remarks on both notions in his book (Drwięga, 2002: 80-82).

${ }^{2}$ Mass publication of images in media is a symptom of the culture of narcissism; images of the body become the object of visual consumption, and at the same time testify to the possibilities of objectifying body via image. 
material for scholars to be interpreter and explore both the possibilities offered by body and by image, but my aim here is not to analyse the wealth of artistic output, but rather to theorise what is happening between body and image.

Phenomenology develops the problem of images of consciousness and, maintaining its distance from empiricism, it emphasises the representing perception rather than the representation. It is the intentional awareness of perception that initiates the process in question. It is there, under the influence of the multiplicity of ways in which the object is presented to the senses, that image is created. One needs to note, however, that the perception of the thing and the perception of the work of art are different, and in certain ways the latter is privileged. In the consciousness, the constitution of the representation takes place, and in the experience, representation is subjected to many immanent acts. The participation of special context is weakened, along with that of the body of the participating person; both are put in brackets. The relation of the viewer's body and the artefact-work prove insignificant for all that is happening in the consciousness, and the physical picture hanging on the wall, as well as our presence in front of it, are necessary, but merely initial conditions. Specific theories bring out various aspects of the dynamics playing out in the consciousness. In Roman Ingarden's aesthetics, intentional image is a scheme, constituting the basis for successive acts that aim at capturing the aesthetic value. Gaston Bachelard, on the other hand, sees internal images as original impulses, in which the world shows itself as meaningful. They are active and organised in a specific manner; he calls them primordial images, which are a sort of archetypes embedded in our unconscious, primary and foundational in relation to images. Primordial images deposited in the depths of the human psyche give human beings the possibility of reconciling the spirit and the matter, making us primarily grounded in the cosmos (Bachelard, 1994: $5,7,58)$. This is achieved by the creative imagination of the dreamer, which also has the power to capture being, to give it presence in the images it creates. The imaginative work of the scholar, on the other hand, turns images into concepts, and thus cuts them off from the symbolic sources of being. Creating representations happens through endowing the visual with the male (Animus) or female (Anima) element, as well as through tying them with the qualities of the elements of earth, water, fire, and air: paradoxically engaging the corporeality of the dreamer. In The poetics of space Bachelard illustrates the process of revealing the symbolic sources, using the example of the type of dream, which revolves around the house. He first invokes the bodily experience of the physical spaces of the house, the room, the attic, the basement, and then transcends what is physical, giving us a sense of reconciling the bodily and the spiritual in the human being (Bachelard, 1994). The beginning of the dream is the real object (a house, some fruit, a flower), captured by the imagination as an image, 
reinforced, broadened, and coloured with qualities of the proto-images. It becomes fiery, feminine, airy, masculine etc. Placing accent on the creation of images rather than the reception of what is physical brings a person closer to her- or himself, and the surrounding world becomes closer too. Poetic images introduce us to the experience of unity between ourselves and the world more directly than artefacts of painting.

Maurice Merleau-Ponty, on the other hand, offered a very original, and at the same time heuristic, approach to corporeality. His works have become inspiration for scholars interested in the problematics of the body but have also allowed us to look at body-image relations from a new perspective. Body according to the French philosopher - possesses a pre-reflexive cognition in the context of other bodies and things: its intentionality situates it in relation to the surroundings. Body is not a physical object (Körper), but it is also a living body (Leib). The philosopher expands on the concepts formed by Edmund Husserl: the living body is for him expressive by nature, he calls it "our own body, [which] is in the world as the heart is in the organism" (Merleau-Ponty, 2001: 235) it is "the origin of the rest, expressive movement itself, that which causes them to begin to exist as things" (Merleau-Ponty, 2001: 169). Body is not a living centre in which the human being and the world open to one another. In this being with the world, the body of the painter best expresses freedom in the sense-making inhabiting of space, because it is "lent to the world" and "transforms the world into painting". The artist can make her body become "an intertwining of vision and movement" (Merleau-Ponty, 1964: 162). Image is the result of this intertwining. For the bodily consciousness it is neither a physical artefact, nor is it a representation in the conscious "I". Concerning images, "we have thoughtlessly believed that a design was a tracing, a copy, a second thing, and that the mental image was such a design, belonging among our private bric-a-brac" (Merleau-Ponty, 1964: 164). In the encounter of a conscious corporeality with a painting no intentional image is created to be subject to the operations of consciousness; rather, a particular union takes place - unio. In the perception of an image, the physical place and body become insignificant. Responding to the paintings of animals in the Lascaux cave, the French philosopher states: "It is more accurate to say that I see according to it, or with it, than that I see it" (Merleau-Ponty, 1964: 164). This is why the art of painting is so privileged by the French philosopher: thanks to it, we can fully experience our corporeality. Painted images - and one may suspect that not all of them - teach us to experience bodily sensations and give us reasons to be living corporeality; no operation of objectification changes this condition.

Another tendency seriously taking up the issues of revaluation of the human body that I want to bring up here is pragmatism, inspired by the thought of John Dewey. Supporters of this research perspective reject the Kantian model 
of aesthetic experience - disinterestedness - and consider the narrowing of perception to sight and directing it to contemplation does not represent the actual situation of the relation of body and image. The space of museum rooms, ordering objects and beings, makes experience impossible. For Arnold Berleant, the original human situation places body in relation to the surroundings, while beings and the self emerge out of it as defined (Berleant, 2010). This is why his advice is to perceive the landscape of the painting on the level of the body, to smell the air, to feel the gust of wind by means of the view depicted by Constable. And although the images of paintings have been created for the eye, Berleant emphasises the participation of embodied perception, making numerous references to Merleau-Ponty's thought. Our way of approaching the image of a painting should involve corporeality, because the painting, as an artefact, itself moves us away from it. Through the effort of involvement, we are to restore the state of being in the environment.

Richard Shusterman, on the other hand, defines the perceptive capabilities of body as bodily awareness, speaking of a somatic self, always in the context of praxis aiming at broadening the self-awareness of one's own body and self-perfection. For the American philosopher, body is a place in which "one's skills of perception and performance can be honed to improve one's cognition and capacities for virtue and happiness" (Shusterman, 2008a: xii). The status of the mental image is secondary in relation to other internal sensations, while the artistic image is an impulse to move the viewer's body. He opposes those representations of body which make it a tool for other messages: presenting body more as "the attractive object of another person's consciousness rather than the radiating expression of the somatic subject's own probing consciousness of embodied self" (Shusterman, 2008a: x). Bodies, often presented in unnatural poses, arouse sympathy rather than admiration. Shusterman stresses that the ideal artist should depict the body of a person aware of their corporeality rather than an image of an object of visual consumption, or a body constructed after a perfect model. Such aims may be achieved by a dancer or a performer, and it is this non-pictorial art that the American scholar focuses on. Image is not able to reflect the condition of body.

Since image always presents body as a static object, in some sense objectified, Shusterman believes that the performative aspects of the creation of image best reflect the behaviour of body towards art, which is not reduced to image. He analyses photography and distinguishes it from the kind of photo that is a static image of a person: photography is a complex process at the end of which we receive the photographic image. Pragmatic aesthetic experience happens in the process of its creation. In this case, as in phenomenology, it is not about image as an artefact that is neutralised, but - unlike in phenomenology - the emphasis is placed on the body involved in the process of creating the photo. While phenomenology reconciles body and image within 
broadened consciousness (intentional and creative), pragmatism exposes the active bodies of the photographer and the model, which are in tactile and individual relations.

The latter approach situates the relations of body and image in the context of the idea of incarnation, which legitimises the creation of depictions. This approach includes the theology of the icon and Belting's theory, which explores the area of cultural anthropology in order to broaden the scope of art history's research interests.

The problem of body and image, if we approach it from the perspective of incarnation, first and foremost concerns the icon, which is a central element of liturgy in the Orthodox Church. The relation we are interested in is narrowed to sacral art, whose raison d'être becomes the Revelation. This is why it is theology that establishes the rules of creating an image. The justification for imaging God is, however, played out on three relatively autonomous plains: the biblical, the philosophical and the legendary plain. In the Christian religion, God becomes incarnated in a human body and is born of a woman as Jesus Christ. The debate over Christ's nature, and namely over His humanity, is closely connected with the debate over the nature of image and the cult of images. The victory of iconophiles, after long theological disagreements, which sometimes took on a bloody form, has established a whole new formula of image, absent before that time, in both Judaism and in the Hellenic culture. The true icon of Christ is the Eucharist, which gives presence to God, while the image of Christ, written on the plank, refers us to the original, but is not identical with it (Melion \& Wandel, 2015: 461-488). There is an essential difference between image and its model. John of Damascus explains: "I am emboldened to depict the invisible God, not as invisible, but as he became visible for our sake, by participation in flesh and blood", and later: "I do not venerate matter, I venerate the fashioner of matter, who became matter for my sake and accepted to dwell in matter and through matter worked my salvation." (St. John of Damascus, 2003: 86). At the same time, however, without image there is no access to the original; image reflects the similarity to the original, and not to the apparition of Christ. It is supposed to bring perception closer to the non-pictorial reality. And it is for these reasons that its creation is strictly canonical and is subject to approval by the Church. This is because the icon is theology, it is a statement on the body of the incarnated God as Logos and is a declaration of "a confession of faith in the historical Incarnation" (Meyendorff, 1979: 45). It transcends symbolic representation (the image of the lamb) as well as mimetic ones (like biblia pauperum), becoming a space of moving into a spiritual, non-visual world, it is - as Władysław Panas describes it - a place of transcending the original sin and its consequences (Panas, 1982: 337). The icon is a witness of spiritual reality and in this sense, saints are icons first and foremost, while their representations point to this reality. This is why 
represented body is reduced to a scheme, without giving satisfaction to the senses. Relation with an icon is a relation of contemplation, "of careful, prayerful gazing, more real, authentic contact with painterly-charismatic reality", as Jerzy Nowosielski puts it (Nowosielski, 1998: 153). However, full contact with the icon takes place within a liturgical community, among song, incense and the twinkling flames of candles falling on the icons. It is in this organised environment that participation and contemplative gazing take place, not in cold museum rooms. Icons are carried around in processions, anointed with incense, and kissed. Liturgy, in which the icon is a central point, engages the entire human being, with all of our spiritual and sensual powers, as well as the body, and raises art to the rank of sacramental or quasi-sacramental operations. The viewer's body is neutralised and made static, and interchangeably engaged performatively in the liturgy. Body and image enter into a relation with one another, although this is not a situation of spontaneity and free choice, but one that is ordered and codified through strictly defined gestures, attitudes and sounds. There is a sharp tension between the static and the bodily activity, leading ultimately to spiritual experiences.

When theoreticians of the icon draw attention to its theological dimension, Belting, distrustful of theological theories, studies cultural images in use. He does this while distinguishing the era before the image and the era of the image, established by Vasari and continuing in the culture of the West to this day. The age of image is preceded by a time when depictions were not objects of admiration, when they did not show tales but had cultural character, were the medium of symbolic communication with God. They were, as elements of liturgy, integrally bound with place, they participated in battles and won (Belting, 1994). In searching for the first practices constituting images Belting places emphasis above all on the idea of incarnation.

At the dawn of image, there is a direct relation between image and the human body, which, according to the German art historian, is clear and obvious, although today entirely forgotten and abandoned. This initiating impulse was the experience of death - it was the cult of the dead that gave birth to image. Because humans are mortal, they create images, and images of the body - including the face - are a symbolic form of handling death. The scholar turns his attention to the beginnings of culture, to the archaic practices related to the cult of the dead. In his opinion the experience of death gives rise to images. Humans replace the body (Körper) of the dead with their image. The creation of image is a way of prolonging their lives - image allows them to remain among the living: "images once served as vessels of embodiment, replacing the lost bodies of the dead" (Belting, 2011: 84). Artefact-image is at the borderline between absence and presence and this liminal situation with all of its tension is what constitutes the significance of the practice of representation. It is in this way that images allow human beings to handle the mystery of death as the 
absence of a person. However, there is no one way of making the dead person present, since cults of the dead in different tribes have developed different kinds of replacement bodies for the dead: skulls, puppets, masks, votives, and other images, are all just various techniques expressing the same goal. Echoes of these practices are located by Belting in contemporary practices of creating death masks, in photography, in film; they are animated by the same impulse as in the past.

The notion of image deserves closer attention, because Belting uses it with many meanings: applying it to all sorts of visual artefacts, transcending genre although image is not identical with the medium through which it is actualised; image is something between an idea and an imagination, and not just any imagination, but one that is vital for us individually and socially. According to Belting, it is for these unrepresentable communications that the right medium is selected, as well as the way in which they will be visible: "the image shines through the medium" (Belting, 2011: 84) just as the human being by name shines through the body. Belting also uses the notion of image in the ordinary sense. It is the materially/immanently preserved representation, but whereas these images are changeable, historical, the impulse of the image-idea calling them to life is something lasting, although it does not possess - as in Bachelard's transcendentalism - an anchor in primordial image or - as in the case of the icon - in primordial model but belongs to human nature.

If we look at the problem from the perspective of the medium, this replacement body for the image-idea, or consider the relations of body-image-medium, then various connotations of the body are revealed. Belting perceives the human body as the primary, living medium of images; it is a reservoir of images created, absorbed, transformed; it is a place of being with images. It should be noted that he consistently uses the notion of Körper here. This material, biological approach to body allows him to explore many behaviours related to treating body as an object transformed into image.

For Belting, the human being is defined by embodying images in external forms - this is the only way for humans to obtain identity and self-understanding, this is the way that they comprehend their relation to body and can undertake to comprehend themselves as mortal but can also handle the excess of images that surround them. Knowing oneself, others and the world does not happen through reflection, but through embodying internal images in an appropriate medium. Belting rejects Herbert Marshall McLuhan's thought that medium creates the message - media only serve to articulate messages repeated for centuries, and it is as if the message chooses the medium. Medium is the body of idea-image. In a sense, idea-image has a certain advantage over the medium: images wander from medium to medium, but neither idea-image nor the medium are autonomous, neither functions independently, they are always intertwined. Belting brings together artefact-image and the 
human body, referring to the reality of experiencing oneself in the individual and social dimension, to the reality of life. This reference to living practices is for him a test of image's reliability.

After Descartes, reflection on body and image brought the two closer together: this was done within broadened consciousness, where intentional consciousness contains the knowledge of body. At the same time, it was observed that our bodily being with images does not take place in isolation from the process of their creation. It contains an echo of relations between bodies, it is a performative entering into their space, as Shusterman demonstrates - or according to Belting - fulfilling the need of being with bodies through images. This corporeal being with images is paradoxically a possibility of drawing attention away from body and image in contemplation, such as happens with the icon.

\section{BIBLIOGRAPHY}

Bachelard, G. (1994). The poetics of space. The classic look at how we experience intimate places. (J. Stilgoe, Trans.). Boston: Beacon.

Barthes, R. (1981). Camera Lucida. Reflections on photography. (R. Howard, Trans.). New York: Hill \& Wang.

Belting, H. (1994). Likeness and presence: A bistory of the image before the era of art. (E. Jephcott, Trans.). Chicago: University of Chicago Press.

Belting, H. (2011). An anthropology of images: Picture, medium, body. (Th. Dunlap, Trans.). Princeton: Princeton University Press.

Berleant, A. (2010). Sensibility and sense: The aesthetic transformation of the buman world. Exeter: Imprint Academic.

Didi-Huberman, G. (2011). Przed obrazem. Pytanie o cele historii sztuki. (B. Brzezicka, Trans.). Gdańsk: Słowo/obraz terytoria.

Diemer, A. (1981). Kurs elementarny filozofii. Antropologia filozoficzna. (P. Taranczewski, Trans.). Kraków: Papieski Wydział Teologiczny.

Drwięga, M. (2002). Ciało człowieka. Studium z antropologii filozoficznej. Kraków: Księgarnia Akademicka.

Heidegger, M. (1990). Kant and the problem of metaphysics. (R. Taft, Trans.). Bloomington: Indiana University Press.

Melion, W.S. \& Wandel, L.P. (Eds.). (2015). Image and incarnation. The early modern doctrine of the pictoral image. Leiden: Brill.

Mitchell, W.J.T. (2005). What do pictures want? The lives and loves of images. Illinois: The University of Chicago Press.

Merleau-Ponty, M. (1964). Eye and Mind. (C. Dallery, Trans.) (pp. 159-190). In: J.M. Edie $\&$ W. Cobb (Eds.). The primacy of perception and other essays on phenomenological psychology, the philosophy of art, history and politics. Evanson: Northwestern University Press.

Merleau-Ponty, M. (2001). Phenomenology of perception. (C. Smith, Trans.). London-New York: Routledge.

Meyendorff, J. (1979). Byzantine theology. Historical trend and doctrinal themes. New York: Fordham University Press. 
Nowosielski, J. (1998). Inność prawostawia. Białystok: Anafora.

Panas, W. (1982). Sztuka jako iconostas. Znak, 337. Accessed: http://biblioteka.teatrnn.pl/ dlibra/Content/9803/Sztuka_jako_ikonostas_Znak_nr_337.pdf (18.04.2020).

Shusterman, R. (2008a). Body consciousness. A philosophy of mindfulness and somaesthetics. Cambridge: Cambridge University Press.

Shusterman, R. (2008b). Thinking through the body. Essays in somaesthetics. Cambridge: Cambridge University Press.

St. John of Damascus. (2003). Three treatises on the divine images. (A. Louth, Trans.). New York: St Vladimir's Seminary Press. 
